\title{
Obstacles and options for the design and implementation of payment schemes for ecosystem services provided through farm trees in Saxony, Germany
}

\author{
CHRISTIAN SCHLEYER* AND TOBIAS PLIENINGER \\ Ecosystem Services Research Group, Berlin-Brandenburg Academy of Sciences and Humanities, Fägerstrasse \\ 22/23, 10117 Berlin, Germany \\ Date submitted: 1 November 2010; Date accepted: 28 April 2011; \\ First published online: 15 August 2011
}

\section{SUMMARY}

Agricultural crops and pasturelands cover $24-38 \%$ of the global land area, and thus the ecological services that agricultural systems provide are of utmost societal importance. An important determinant of ecosystem services provision from European farmland is the amount and spatial arrangement of trees, shrubs and woodlands that are integrated into the respective landuse systems. This paper uses an institutional economics framework for the analysis of payment schemes for ecosystem services (PES schemes) that enhance the establishment, conservation and management of farm trees and woodlands, elaborating on the reasons for the often very reluctant participation of farmers in these schemes. PES schemes in Saxony (Germany) were selected as a typical example. Obstacles identified included high production costs and opportunity costs for land use, contractual uncertainties, land-tenure implications and heterogeneous societal preferences for ecosystem services of farm trees. Further, since scheme adoption has been relatively low compared with the total area covered by the respective farm tree types in Saxony, the PES schemes alone could not explain the substantial increase in number and size of some farm-tree types, in particular hedgerows. Regionalized premiums, result-oriented remuneration and cooperative approaches are options to improve participation in PES schemes for farm trees. The example of PES schemes for farm trees highlights one of the major challenges for the protection and preservation of cultural landscapes: they are manmade and thus need to be preserved, managed and maintained continuously.

Keypords: agroecosystems, East Germany, institutional economics, payments for ecosystem services (PES), Saxony, trees outside forests

\section{INTRODUCTION}

With estimates for agricultural crops and pasturelands ranging between $24 \%$ and $38 \%$ of the global land area, the ecological

*Correspondence: Dr Christian Schleyer e-mail: schleyer@bbaw.de services that agricultural systems provide are of utmost societal importance (Swinton et al. 2007). Depending on the specific agricultural system, provision of food, fibre and fuel can be accompanied by a range of regulating and cultural ecosystem services, but also by unwanted environmental 'bads', for example habitat loss, nutrient runoff, or pesticide poisoning of non-target species (Zhang et al. 2007). An important determinant of ecosystem services provision from European farmland is the amount and spatial arrangement of trees, shrubs and woodlands that are integrated into the respective land-use systems (Auclair et al. 2000). These landscape elements have been conceptualized as 'farm trees' (items similar to single trees; Arnold \& Deewes 1997), 'farm woodlands' (similar to small forest stands on agricultural land; van der Horst 2006) or 'trees outside forests' (FAO [Food and Agriculture Organization of the United Nations] 2001). The FAO (2000, p. 40) defined them as all trees excluded from the definition of forest and other wooded lands. In this paper, we use the term 'farm trees' to refer both to single trees and more comprehensive groups of trees on agricultural land.

Farm trees and woodlands are considered 'keystone structures' of agroecosystems because of their large ecological values relative to their low abundance. Across a broad spectrum of ecosystems, overall species diversity is strongly linked to a high-quality structure of scattered farm trees and to the fact that they are single trees rather than part of a large consolidated forest patch (Tews et al. 2004; Manning et al. 2006; Gibbons et al. 2008). Farm trees provide many parallel ecosystem services, such as buffering groundwater pollution (Ryszkowski \& Kedziora 2007), controlling surface runoff and soil erosion (Pattanayak \& Mercer 1997), and offering cultural services such as aesthetics and sense of place (McCollin 2000). Only recently has the contribution of farm trees towards climate change mitigation (mainly through enhanced carbon sequestration in vegetation and soils; see Nair et al. 2009; Plieninger 2011) and adaptation (through increasing the resilience of agricultural systems against adverse impacts of changing climate conditions such as drought, erosion or fertility loss; compare Verchot et al. 2007; Manning et al. 2009) been acknowledged. Farm trees also assist adaptive responses of organisms and, thus, can help to overcome the interacting negative effects of climate change and land-use change on biodiversity (Manning et al. 2009).

Given all of these benefits, it is a cause of concern that a number of case studies from around the world have reported 
Table 1 Changes in number, area and row length of farm trees in Saxony between 1992/1993 and 2005 (Source: calculated from land cover data provided by the Saxony State Office for the Environment, Agriculture and Geology, Dresden, Germany).

Data may also include trees outside agricultural areas, for example along roads or water bodies.

\begin{tabular}{|c|c|c|c|c|c|c|}
\hline \multirow[t]{2}{*}{ Farm trees } & \multicolumn{2}{|c|}{ Number } & \multirow[t]{2}{*}{ Change } & \multicolumn{2}{|c|}{ Area/length } & \multirow[t]{2}{*}{ Change } \\
\hline & $1992 / 1993$ & 2005 & & $1992 / 1993$ & 2005 & \\
\hline Scattered fruit-tree meadows & 20528 & 11733 & $-42.8 \%$ & $10724.6 \mathrm{ha}$ & $6146.9 \mathrm{ha}$ & $-42.7 \%$ \\
\hline Woodlots & 39274 & 47891 & $+21.9 \%$ & $9704.2 \mathrm{ha}$ & $10707.7 \mathrm{ha}$ & $+10.3 \%$ \\
\hline Shrublands & 2549 & 4671 & $+83.2 \%$ & 847.3 ha & $1108.0 \mathrm{ha}$ & $+30.8 \%$ \\
\hline Tree rows & 93245 & 140774 & $+51.0 \%$ & $8283.5 \mathrm{~km}$ & $16481.4 \mathrm{~km}$ & $+99.0 \%$ \\
\hline Hedgerows & 27341 & 70815 & $+159.0 \%$ & $2893.4 \mathrm{~km}$ & $6372.8 \mathrm{~km}$ & $+120.3 \%$ \\
\hline Isolated trees & 47716 & 29090 & $-39.0 \%$ & - & - & - \\
\hline
\end{tabular}

a serious decline of farm trees in natural, cultural and recently modified landscapes. For example, a 35\% loss rate of holm oak trees between 1956 and 2003 was found on privately owned farm estates in south-western Spain (Plieninger \& Schaar 2008 ), in southern Germany around $50 \%$ of scattered fruit trees vanished during the second half of the 20th century (Eichhorn et al. 2006), and major declines in hedgerow network structure have been observed throughout Western Europe (Deckers et al. 2005). Among the most common threats are legal or illegal clearing, lack of tree regeneration, pathogens degrading tree health, shrub encroachment, abandonment of traditional grazing regimes and agricultural intensification (Manning et al. 2006).

Similar trends can be observed in the eastern German state of Saxony, where characteristic farm trees include isolated trees, hedgerows, meadows with scattered fruit trees (Streuobst), woodlots, shrublands and tree rows (see Fig. 1 for an example). Here many farm trees have been lost in past decades, particularly in consequence of the intensification of agricultural production implemented under the former German Democratic Republic (GDR) of the 1960s and 1970s (Philipp 1997). Since German reunification in 1990, nature protection and latterly the concept of ecosystem services provided by farm trees have become more prominent. However, at the same time agricultural production has remained intensive. The changes in number and area or row length of the various types of farm trees during this period (1992/1993-2005), as assessed through state habitat and land use inventories, offer a mixed picture: the number and area cover of scattered fruit tree meadows and the number of isolated trees decreased drastically. Other farm tree types, in particular hedgerows, increased equally significantly (see Table 1).

Since the early 1990s, a range of incentive-based schemes have been established that enhance the establishment, conservation and management of farm trees in Saxony. In the European Union (EU) member states, payment schemes for ecosystem services (PES schemes) have often been implemented as part of national or regional rural development plans (RDP). Farmers participate voluntarily in these schemes, which are cofinanced by the EU up to $75 \%$ of the costs, and have to commit to them for five years. Only an individual farmer's income losses, that is, opportunity costs, such as costs for additional labour, machinery and other farm inputs, as well as unrealized income due to lower yields for introducing (or continuing) a certain farming
Figure 1 Exemplary spatial distribution of various types of farm trees in Weißenberg, Saxony (Source: ATKIS $囚-D O P$, (c) Staatsbetrieb Geobasisinformation und Vermessung Sachsen 2010).

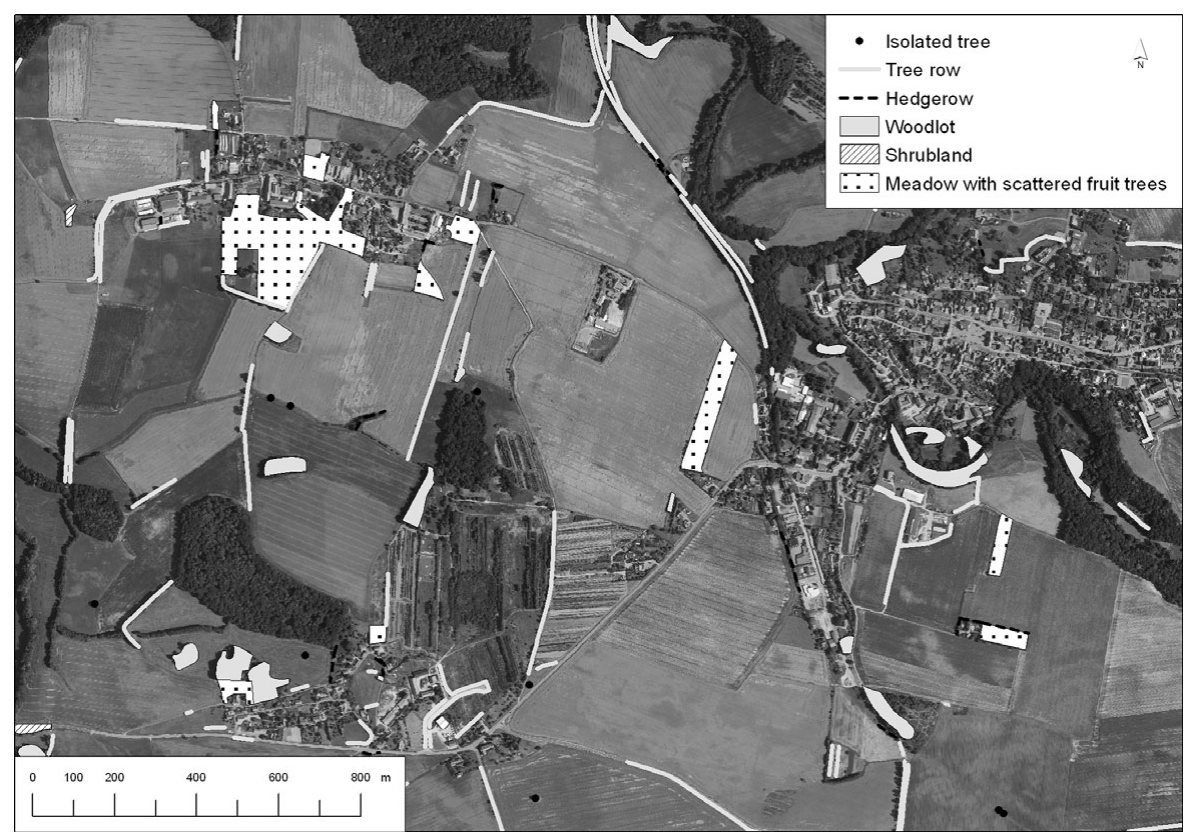


practice, are to be compensated, plus a maximum incentive component of $20 \%$ (see for example Bruckmeier \& Schubert 1996). In Saxony, all RDPs, here coined 'environmentally friendly agriculture' (Ummeltgerechte Landwirtschaft [UL]), implemented between 1994 und 2008 included only one measure explicitly targeting farm trees, concerning specifically the maintenance of scattered fruit-tree meadows.

Complementing these PES schemes, several contractual nature protection schemes (Vertragsnaturschutz) for agriculture, fish ponds and forestry were established in Saxony and all other German states in the 1990s. These schemes are voluntary, introduced with variable but limited contract duration, and contain rather flexible measures in terms of design and related premiums. Environmental authorities at the district level conclude contracts with individual or groups of farmers, or so-called Landcare Associations (LCAs, Landschaftsplegeverbände), and monitor and enforce them. In Saxony, with respect to farm trees, among others the plantation and renewal of scattered fruit trees, hedgerows, shrubs and riparian woods have been financed (Deimer $e t$ al. 2007).

In Saxony, there are also incentive-based approaches and initiatives for farm trees in place that derive their financial means from private sources, more precisely from project developers and consumers. Here all 14 LCAs in Saxony, which operate at the district level, have played an important role for the plantation and maintenance of farm trees far beyond their activities in the state-financed contractual nature protection schemes. The LCAs are voluntary collaborations between nature-protection associations, farmers, land owners and municipalities, working mainly to protect the native fauna and flora and the biological resources in cultural landscapes, and to support environmentally friendly landuse systems and regional economic development (Bluemlein 2009). In Saxony, LCAs have been, among other activities, planting and maintaining hedgerows and riparian woods (SMLEF [Sächsisches Staatsministerium für Landwirtschaft, Ernährung und Forsten] 1998).

Compensation and land consolidations funds have recently become an important private source of financial means for the promotion of farm trees. In 2008, the concept of 'habitat banking' (Ökokonten) was implemented in Saxony as an approach to pool financial obligations for compensation from different individual developers to implement larger and more comprehensive compensation measures, including planting of scattered fruit trees and hedges. Coordinated by a state-owned 'habitat banking agency' (Sächsische Landsiedlung $\mathrm{GmbH}$ ), farmers, LCAs and other land users voluntarily offer specific measures that create new or enhance the quality of existing habitats. Importantly, once the contributors of the measures have received the one-time payment, they are legally obliged to ensure adequate and permanent conservation and management of the established habitat (SMUL [Sächsisches Staatsministerium für Umwelt und Landwirtschaft] 2010b). Another example for a voluntary privately-financed farm tree related project is the 'Regional Scattered Fruit Cycles'
(Regionale Streuobstkreisläufe) project that was initiated in 2008 by the German Association for Landcare to provide financial and practical incentives for harvesting the fruit of scattered fruit trees. In three pilot regions in Saxony, comprehensive extension services for owners and land users of scattered fruit-tree meadows have been offered, including advice on support programmes, maintenance of trees and meadows and options for processing of fruits (DVL [Deutscher Verband für Landschaftspflege] 2010).

These incentive-based policies are complemented by two regulatory command-and-control approaches. The Saxonian Law concerning nature protection and landcare (Sächsisches Naturschutzgesetz), implemented in 1992, legally protects certain types of farm trees. Among other things, it is generally forbidden to remove or damage shrubs and scattered fruittree meadows. Additionally, specific landscape elements, such as individual hedgerows, tree rows and isolated trees may be designated for protection by the state authorities if the respective elements are characteristic of the surrounding landscape. The cross compliance element within the EU Common Agricultural Policy (CAP), introduced in 2003, stipulates that farmers will only receive (full) direct payments if they respect defined standards based on existing EU and national regulations (Dupraz et al. 2010). In this context, Germany has established specific standards for good farming practices (GFPs), including the preservation of farm trees.

The performance of PES schemes and other policy instruments can be evaluated against a number of criteria (see for example Bemelmans-Videc et al. 2007), the most common of which are effectiveness and cost-effectiveness. While effectiveness refers to the accuracy and completeness with which the specified goals or policy objectives can be achieved, cost-effectiveness is determined by relating the resources expended (costs) to the accuracy and completeness of goals or policy objectives achieved. Considerations of costeffectiveness refer to the economic costs that society incurs for carrying out a certain policy. Two main cost categories can be distinguished. 'Production costs' refer to the costs of the actual activities that have to be undertaken by actors to provide ecosystem services. Cost differences may arise if an ecosystem service can be generated in different ways. For example, water pollution may either be reduced by limiting the use of fertilizers and pesticides, or by planting riparian woodlands alongside surface water bodies. Furthermore, the costs and benefits of certain individual measures to provide ecosystem services are subject to spatial and temporal variations; for example, the costs and benefits of hedgerows to reduce soil erosion due to water and wind differ depending on the slope and the soils of the adjacent land plots, as well as on the frequency and the time of year when maintenance is carried out. Production costs also include opportunity costs, which are the profits foregone when carrying out the activities prescribed by the PES scheme. For example, a commitment to use grassland extensively deprives a farmer of the opportunity to realize higher yields which would be possible with intensive grassland farming. 'Transaction costs' are not only incurred 
by the private sector, but also by the public sector at all administrative and political levels. Birner and Wittmer (2004) distinguished between decision-making costs and implementation costs, including monitoring compliance with policy requirements and enforcement measures.

The effectiveness and cost-effectiveness of policy instruments in general, and PES schemes in particular, are strongly influenced by the characteristics of the ecosystem, the ecosystem services and the related transactions targeted (Hagedorn et al. 2002; Kroeger \& Casey 2007). Conservation and management of farm trees is connected with multiple transactions, including planting, pruning and/or coppicing of trees and shrubs, producing and selling firewood and fruit, and 'producing' cultural ecosystem services for people living in or visiting the area. Most ecosystem services provided by farm trees are jointly produced in 'bundles' (Raudsepp-Hearne et al. 2010) and can consequently hardly be separately regulated. For example, planting and maintaining hedgerows for the reduction of soil erosion due to wind and water concurrently supplies habitats for a wide range of species and, thus, may increase biodiversity. Further, the resource units are both site-specific and immobile.

It is also important to consider that farm trees are part of semi-natural ecosystems that have been shaped by human uses. These are low-intensity 'wildlife-friendly farming systems' (Fischer et al. 2008) that need to be maintained in a regular fashion through extensive land management. Characteristic system attributes are co-occurrence of agriculture and biodiversity, landscape continuity and heterogeneity, and a fine-grained variability in land cover and value for biodiversity (Fischer et al. 2008). Establishment and management of farm trees is knowledgeintensive and specific, and there is also some moderate capitalspecificity involved. For example, special machineries or technologies for pruning trees or maintaining hedgerows often cannot be used for other purposes. Although the production process of farm trees depends to some extent on stochastic events, such as rainfall, the related natural causeeffect relationships are rather regular, continuous and wellknown in farm tree ecosystems.

Employing the institutional economics framework described above with its focus on production and transaction costs related to policy instruments as well as on the impact of the characteristics of targeted resources, this study sets out to analyse the obstacles to design and implementation of cost-effective PES schemes for farm trees. Thus, we seek to contribute towards the design of improved policies to promote the ecosystem services provided by farm trees. Saxony is a typical case where farm trees are characteristic elements in a cultural landscape that has increasingly been used for intensive forms of agriculture. As in many other countries in central Europe, agricultural intensification has resulted in substantial loss and degradation of many farm tree types. From a policy perspective, Saxony is pertinent due to the variety of PES schemes that have been introduced over the last two decades to counter this trend. Further, these developments and

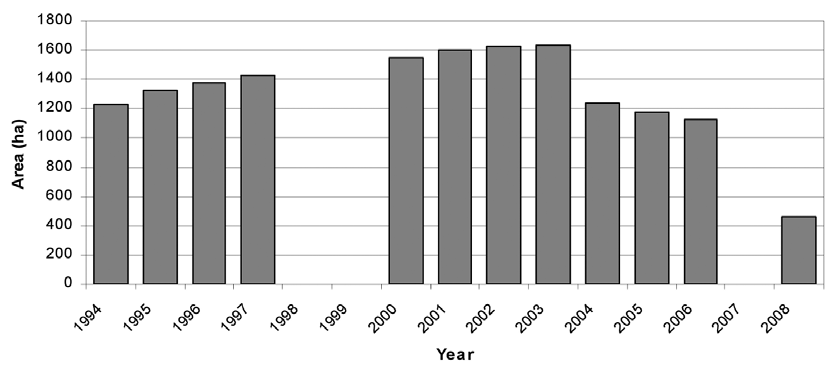

Figure 2 Area supported by EU cofinanced PES schemes (Ummeltgerechte Landwirtschaft, UL) for the maintenance of scattered fruit-tree meadows in Saxony between 1994 and 2008. No data available for 1998, 1999 and 2007 (based on Bruckmeier \& Schubert 1996, p. 75; Deimer et al. 2007, pp. 86, 94, 96; SMLEF 1998, pp. 47-51; SMUL 2009, p. 45).

their outcomes can be traced explicitly, since comprehensive statistics on both land cover and agricultural support are available.

\section{OBSTACLES TO PARTICIPATION IN PES SCHEMES FOR FARM TREES}

While PES schemes for farm trees in Saxony exist, they are often characterized by a narrow range of measures, the reluctant participation of farmers and other land users, and a limited performance. The supported land area under the EU cofinanced PES schemes (Ummeltgerechte Landwirtschaft 1-3) 1994-2008 never exceeded 1700 ha (Fig. 2) and was during the whole period well below $15 \%$ (generally $<10 \%$ ) of the total area covered by scattered fruit-tree meadows (see Table 1). The impact of the contractual nature conservation schemes has also been rather low. For example, between 2000 and 2006 , only 49 ha of hedgerows were planted, a further 120 ha of hedgerows regenerated and supplemented, and 2700 scattered fruit trees planted on 21 ha (Deimer et al. 2007). With respect to privately financed PES schemes, in 1997, 98 measures were carried out by LCAs to plant $37 \mathrm{~km}$ of hedgerows and other protective woodlands (SMLEF 1998, pp. 114f., 126).

Several potential obstacles exist for the participation of farmers in PES schemes for farm trees in Saxony, namely (1) high production costs and (2) opportunity costs for land use, (3) contractual uncertainties, (4) land tenure implications and (5) heterogeneous societal preferences for ecosystem services from farm trees.

\section{Production costs}

Relatively high initial investments are needed for the plantation of farm trees and the continuous efforts necessary to maintain them contribute substantially to the reluctance of farmers and other land users to engage in PES schemes for farm trees (see for example Brodt et al. 2009). For example, Nottmeyer-Linden et al. (2000, p. 107) calculated costs of $c$. $€ 26$ per tree $(€ 1 \approx$ US\$ 1.43 , May 2011) 
for the plantation of scattered fruit trees and an annual $€ 2$ per tree for maintenance (pruning at 10 year intervals). They recommended scattered fruit-tree meadows required payments $c$. 1.1 times the usual compensation payments needed for 'normal' extensive grassland use. For the plantation of hedgerows and shrubs, they calculated values of $€ 4.60 \mathrm{~m}^{-2}$ for plantation and $€ 511 \mathrm{ha}^{-1} \mathrm{yr}^{-1}$ for maintenance (coppicing at 10 year intervals). In particular, the premiums offered in the PES schemes cofinanced by the EU are often perceived as insufficient to compensate for the costs incurred. Here, premiums paid amounted to $€ 205 \mathrm{ha}^{-1}$ of scattered fruit-tree meadow plus $€ 3$ tree $^{-1}$, up to a total maximum of $€ 450 \mathrm{ha}^{-1}$ (see for example Bruckmeier \& Schubert 1996). Further, these PES schemes only allowed for homogenous annual premiums, not covering the initial investment costs. Investments in farm trees are also very asset-specific, that is they cannot easily be transferred across time and space once they have taken place. For example, a hedgerow planted by a farmer to reduce wind erosion or to increase biodiversity cannot simply be moved to another spot. What is more, planting and maintaining farm trees is very knowledge-intensive (Brodt et al. 2009) and may demand the use of special machinery, resulting in costs which are not covered by EU or state-financed PES schemes.

\section{Opportunity costs of land use}

The leasehold prices for arable land in Saxony, which accounts for $79 \%$ of the agricultural land (SMUL 2010a), are substantially higher than for grassland. Leasehold prices for arable land and grassland have been increasing steadily since 1991 , from about $€ 71 \mathrm{ha}^{-1}$ and $€ 51 \mathrm{ha}^{-1}$ in 1991 to about $€ 126 \mathrm{ha}^{-1}$ and $€ 72 \mathrm{ha}^{-1}$ in 2007, respectively (Winkler et al. 2010). Thus, farmers face comparatively higher opportunity costs for land use on arable plots, as opposed to grassland areas. Yet, these differences in opportunity costs are not reflected in the premium levels of most of the PES schemes for farm trees offered by public bodies in Saxony. Instead, other agricultural policies may even increase the opportunity costs for planting farm trees, for example by providing payments for growing energy crops. However, it is precisely here where many of the ecosystem services provided by farm trees are in short supply and where demand would be high, in particular, for preventing soil erosion due to wind and water, but also for maintaining biodiversity (Reeg 2008). Examining the correlation between local natural conditions and demand for PES schemes in general, Osterburg (2000) found that the demand for PES schemes was significantly higher in regions with relatively poor natural conditions due to poor soil quality or being mountainous regions, and in regions with low average yields, low stocking rates and low land-use intensity. Further, he showed that demand for PES schemes decreased if the compulsory environmental requirements defined in the related measures increased, thus inducing substantial changes in farming practices. This would be relevant for farm trees that rely on long-term maintenance activities. Further, if the density of farm trees on a particular plot exceeds a particular point, the entire plot may not be regarded as an 'agricultural area' and thus may not be eligible for EU direct payments. Currently, this is a grey area in German law and is decided on a case-to-case basis by the responsible agricultural authorities (Chalmin 2008). This constitutes, however, a clear disincentive for land users depending on these often fairly substantial payments. It may even prove to be a sufficient incentive for the removal of tree rows and (parts) of hedgerows adjacent to plots, in order to increase subsidized farm size and, thus, income.

\section{Contractual uncertainties}

PES schemes in the context of EU rural development regulations and many state-financed schemes usually require the participation of farmers for at least five years. The continuation of such contracts after the contract period, however, is not guaranteed by the state. In cases that require investments, this may negatively affect the willingness of farmers to commit themselves to such contracts and, consequently, the introduction of long-term contracts has been suggested (Hampicke 2001). Such long-term contracts may also avoid the problem that in cases where a conservation benefit has been created which cannot be easily reproduced elsewhere the farmer is in the position to bargain for higher payments by threatening not to renew the contract (Wätzold \& Schwerdtner 2005). However, Stern (2003) argued that long-term contracts would impose risks on both contracting partners: (1) political and administrative authorities at state level would not have the option to end the contract prematurely free of charge, for example in response to budgetary problems and (2) farmers, in turn, would lose the option to react flexibly to changing market prices.

\section{Land tenure implications}

In most PES schemes for farm trees, farmers are conceptually treated as landowners, an assumption that is not supported by the reality of many European agricultural regions in general (see for example Hagedorn 2004), and in Saxony where leasehold is prevailing in particular. Although the share of leased agricultural land has been decreasing in Saxony, from $89 \%$ in 1993 to $79.7 \%$ in 2007 , leasehold remains dominant (Winkler et al. 2010, p. 4). In order to participate in PES schemes fostering the planting of farm trees, farmers need the formal and official agreement of landowners. However, apart from contractual nature protection schemes, PES schemes in Saxony do not allow for compensation of negotiation costs or the acquisition of land. This problem of negotiation costs is even more pronounced in regions with fragmented land ownership, as is the case in Saxony. While most agricultural enterprises (5440) farmed $<100$ ha, there were 467 enterprises farming $\geq 500$ ha (Fig. 3) (SMUL 2010a). Yet, there is also a risk involved on the part of landowners that, if they agree to the planting of farm trees on their land, future potential leaseholders may not want to lease land covered by farm trees 


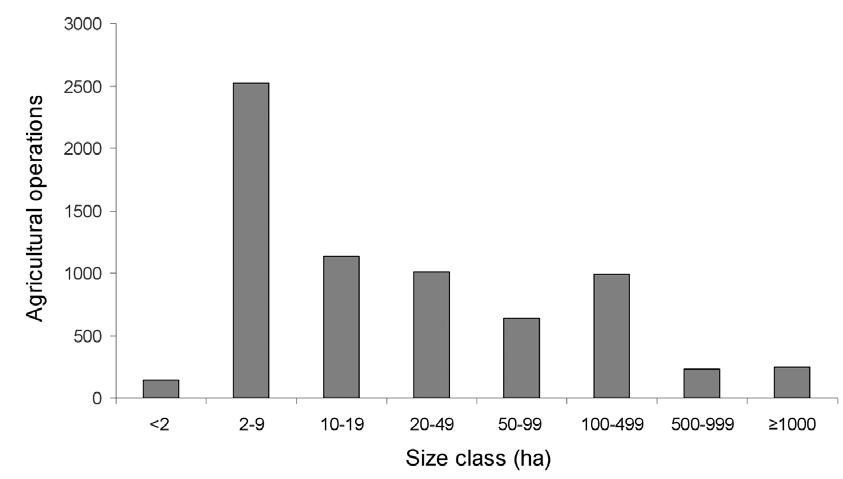

Figure 3 Number of agricultural operations per farm size class in Saxony, 2009 (Source: SMUL 2010a).

or may want to bargain for lower land rents because of this. Further, a lock-in effect may be observed, since investments in farm trees only break even after the end of a current lease contract. Here, a land owner may opt for increasing land rent. In turn, if the current landlord died and his heir raises rent, the investment may be endangered if the farmer does not want to or cannot pay the elevated rent.

\section{Heterogeneous societal preferences for farm tree ecosystem services}

The level of financial means available for incentive-based schemes fostering farm trees depends to a great extent on the societal preferences for the various ecosystem services provided by farm trees. This is particularly important for privately financed schemes, such as 'Regional Scattered Fruit Cycles' (DLV 2010) or most of the activities carried out by LCAs (Bluemlein 2009). However, this 'societal willingness to pay' does not necessarily accord with environmental scarcity as assessed, for example, by environmentalists and other experts (see for example Sayadi et al. 2009). Some symbolic 'charismatic' species (Tisdell \& Swarna Nantha 2007) or landscape features may attract much more public attention than others. In consumers' perceptions, aesthetic aspects may also play a more important role than detailed materialistic ecosystem services accounts, which are favoured by natural scientists. 'Willingness to pay' seems high for some types of farm trees, especially for scattered fruit-tree meadows (see Zander \& Waibel 2005). In other cases, such as woodlots and shrublands, which are important 'keystone structures' of agroecosystems yet often have less aesthetic value, the necessary financial means may be difficult to raise from private sources.

\section{POLICY OPTIONS FOR IMPROVING PES SCHEMES FOR FARM TREES}

What can be done to increase the participation of farmers in PES schemes for farm trees? Based on our investigation, we suggest the following policy options:
(1) Regionalized premiums for PES schemes that better account for variances, such as in soil quality and land use (arable or grassland), that result in high opportunity costs for farmers in some areas, may increase participation. However, implementing such a differentiated approach would entail higher transaction costs for administration and planning. Contractual nature-protection schemes for farm trees that are project-oriented (where premiums and conditions are negotiated individually based on calculations in project plans) seem to show promising levels of cost-effectiveness, particularly for complex measures related to farm trees (Bielig 2003). Since state budgets for such schemes are usually limited and their application is often restricted to high-priority conservation reserves (Bielig 2003), it is worth exploring ways of introducing regionalized premiums in EU cofinanced agrienvironmental schemes.

(2) Farmers' opportunity costs for planting farm trees may also be reduced by critically evaluating agricultural and other policies, such as payments for growing energy crops that reduce incentives for farmers to plant farm trees (see Fargione et al. 2008) or even motivate farmers to reduce the size and number of farm trees on their plots.

(3) The range of measures for farm trees within publiclyfunded PES schemes should be broadened to allow for the plantation and maintenance of those farm tree types for which private funds are difficult to raise, including shrublands, woodlots and tree rows.

(4) In areas with a high share of leasehold and fragmented land ownership, premiums in PES schemes for farm trees should be higher to allow for compensation of negotiation costs between landowner and leaseholder. Here, intelligent contracts accompanied by effective mechanisms to reduce potential conflicts may reduce potential long-term risks for all contract partners when committing to PES schemes for farm trees. Further, the implementation of long-term payment schemes beyond the usual five year period should be considered. Constraining budget issues may be reduced by inducing cooperation agreements between different public and private bodies.

(5) Since the planting and maintaining of farm trees is often very intensive of labour, time and knowledge, cooperative approaches may be helpful to reduce related costs, for example, for special machinery. Coordination between farmers is also required because the specific spatial configuration of farm trees across landscapes is critical to the provision of many ecosystem services, for example water purification services (Goldman et al. 2007). Successful examples of such environmental cooperatives can be found in the Netherlands (Slangen \& Polman 2002). Alternatively, demonstration projects could induce farmer-to-farmer discussions about options for support, plantation, maintenance and regional marketing (Brodt et al. 2009). Here, LCAs (Bluemlein 2009) could play a greater role. 
(6) Agricultural economists regularly stress that the effectiveness and cost-effectiveness of PES schemes would increase if outcome-oriented rather than measureoriented payments were to be applied (see Wätzold \& Schwerdtner 2005). Furthermore, result-oriented remuneration would increase the innovation potential, reduce information asymmetries between state authorities and land users with respect to the latter's 'real' opportunity costs and quality of measures for farm trees carried out, and promote self-interest, cooperation, continuity, and farmers' intrinsic motivations and interests regarding environmental problems (Gerowitt et al. 2003). However, the high complexity, heterogeneity and variability of ecological systems, such as farm trees and woodlands, make it difficult to apply result-oriented remuneration. Planting activities, for instance, may result in rather stochastic, uncertain and very much delayed (environmental) effects, such as the recurrence of certain rare plants or birds nesting in a particular hedgerow or woodlot. Thus, a farmer's 'investment' would be confronted by a highly uncertain premium level, or even no premium at all (Hampicke 2001).

(7) Finally, for specific and ecologically very valuable farm tree types GFPs may also include provisions to ensure their maintenance. Here, the fundamental question is which activities (or omissions) a land user should be paid for and which he should be obliged, by GFP or even by law, to provide (or to omit) without compensation. In general, the protection of abiotic resources, such as soil and water, is perceived predominantly as a basic component of GFP, whereas the active management of biotic and aesthetic natural resources, such as farm trees, is often regarded as exceeding this standard and, thus, would require compensation (Weins 2001). In this context, Germany has established specific standards for GFPs, among others for the preservation of landscape elements, such as farm trees. It is forbidden to fully or partly remove (i) hedgerows longer than $20 \mathrm{~m}$, (ii) tree rows of at least five trees and longer than $50 \mathrm{~m}$, (iii) woodlots $100-2000 \mathrm{~m}^{2}$ in extent and (iv) isolated trees which are designated as natural monuments (Knickel et al. 2001). While extending the GFP provisions to maintenance of farm trees and regarding it as part of the 'social obligation of property' may be ethically justified, there are cases where it may be appropriate and useful to grant compensations nonetheless. This includes cases where land users are likely to give up farming completely due to the costs incurred because of the obligations, and where monitoring compliance is not possible or very costly, and thus farmers may be tempted to ignore the obligations.

\section{DISCUSSION}

We have shown that there has only been a very restricted portfolio of measures within EU cofinanced PES schemes available to foster the development of farm trees in Saxony. This finding is in line with the results of an evaluation of agrienvironmental schemes in the EU, where it was strongly recommended that a landscape approach should be followed that ensures the inclusion of farm trees, such as hedgerows and willow plantations, in EU funding programmes (European Commission 1998, pp. 140f). Most PES schemes in Saxony have focused on the maintenance of scattered fruit-tree meadows, though some project-related funding (state and private sources) for planting of scattered fruit trees and, to a lesser extent, for hedgerows, shrubs and riparian woods, was also identified. Moreover, the participation of farmers and other relevant actors in these schemes has been relatively low compared with the total area covered by the respective farm tree types.

In Saxony, existing PES schemes and regulatory commandand-control policies have been insufficient to stop the drastic decline of scattered fruit-tree meadows and isolated trees. More precisely, while the protection of farm trees against intentional harms by the implemented command-and-control approaches can be considered as rather effective in general, there is no related legal obligation to actively manage the protected farm trees and to carry out management practices, such as tree regeneration or the regular pruning needed for long-term conservation of biodiversity and ecosystem services. These gaps may be responsible for the great reduction since 1992 of isolated trees (often over-aged and in need of regeneration) and meadows with scattered fruit trees (not viable without active management) (Table 1). Existing PES schemes and regulatory command-and-control policies are likely to have dampened the decline to some extent. Further, the portfolio of measures and the participation in PES schemes can only partly explain the increase in number and area of other farm tree types, such as woodlots, hedgerows, shrublands and tree rows. Possible explanations for this development include that farm trees and woodlands have expanded in size due to natural growth that has not been actively restrained by land users; perhaps these areas have been treated as set-aside. It may also be the case that some farmers or other land users have planted hedgerows even without financial assistance. Idealistic rationales may have been at work here. Indeed, farmers often used to provide these societal benefits voluntarily (Vatn 2010). Here, the introduction of PES schemes may increase the danger of 'crowding out environmental virtues', meaning that farmers will only provide farm trees if they are paid for it.

Further, farmers may have not participated in PES schemes for farm trees because of the restrictions that would have been involved with formal contracting. In this case, they may have valued the option to reverse their decision (to grow farm trees) without possibly high exit costs. Alternatively, farmers of very small areas ( $<2$ ha) may not have been able to participate in EU cofinanced PES schemes because they were not eligible. Here, the only recently developed and implemented alternatives in Saxony ('habitat banking', 'regional scattered fruit cycles') may foster the planting and maintenance of farm trees in the future, particularly for such small farmers. 


\section{CONCLUSIONS}

The findings of this review allow some lessons that can be learnt for the wider debate on PES schemes in agroecosystems, as many obstacles to the participation of farmers in PES schemes for farm trees are also relevant for other agroecosystems. These obstacles include high production costs which are often not fully compensated by the premiums paid and inflexible contracts in the context of PES schemes that, for example, do not take changing market prices into account. The specific features of farm trees, however, bring particular aspects related to land tenure, the temporal (longterm investment) perspective and high opportunity costs to the forefront. Solutions that may be developed to overcome these problems for PES schemes for farm trees are likely to improve other PES schemes dealing with similar resource characteristics. The most powerful options for improving PES schemes are regionalized premiums, result-oriented remuneration and cooperative approaches. The example of PES schemes for farm trees also highlights one of the major challenges for the management of ecosystem services in cultural landscapes: cultural landscapes are man-made, unlike primeval forests, and thus need to be preserved, managed and maintained continuously. This, however, demands constant efforts, not only financially, but also for improving the design of PES schemes and other policy approaches.

\section{ACKNOWLEDGEMENTS}

Funding was provided by the German Federal Ministry of Education and Research (FKZ 01UU 0904A). We also thank Chris Hank, Yvonne Dinter, Kathrin Trommler and Martin Mantel, as well as three anonymous reviewers and the Editor in Chief of Environmental Conservation, Nicholas Polunin, for their help and valuable comments. Thomas Reimann of the Saxonian State Office for the Environment, Agriculture and Geology, Dresden, facilitated access to the data of the state habitat and land-use inventories.

\section{References}

Arnold, J.E.M. \& Deewes, P.A. (1997) Farms, Trees, and Farmers. Responses to Agricultural Intensification. London, UK: Earthscan.

Auclair, D., Prinsley, R. \& Davis, S. (2000) Trees on Farms in Industrialised Countries: Silvicultural, Environmental and Economics Issues. Kuala Lumpur, Malaysia: IUFRO.

Bemelmans-Videc, M.-L., Rist, R.C. \& Vedung, E. (2007) Carrots, Sticks and Sermons: Policy Instruments and their Evaluation. New Brunswick, NJ, USA: Transaction Publishers.

Bielig, A. (2003) Ökonomische Analyse des Vertragsnaturschutzes: Rahmenbedingungen, Funktionsweise und Implikationen. Hamburg, Germany: Kovac.

Birner, R. \& Wittmer, H. (2004) On the 'efficient boundaries of the state': the contribution of transaction-costs economics to the analysis of decentralization and devolution in natural resource management. Environment and Planning C-Government and Policy 22: $667-685$.
Bluemlein, B. (2009) Land care in Germany [www document]. URL http://www.lpv.de/fileadmin/user_upload/data_files/ Publikationen/English_Documents/Landcare_in_Germany.pdf

Brodt, S., Klonsky, K., Jackson, L., Brush, S.B. \& Smukler, S. (2009) Factors affecting adoption of hedgerows and other biodiversityenhancing features on farms in California, USA. Agroforestry Systems 76: 195-206.

Bruckmeier, K. \& Schubert, D. (1996) Umweltgerechte Landwirtschaft in Sachsen: Die Umsetzung der flankierenden Umweltmaßnahmen aus der Reform der Gemeinsamen Agrarpolitik von 1992. Sozialwissenschaftliche Untersuchung. Schriftenreihe der Sächsischen Landesanstalt für Landwirtschaft 1: 57-102.

Chalmin, A. (2008) Agroforstsysteme in Deutschland. Landinfo 7/2008 [www document]. URL http://www.agroforst.unifreiburg.de/ download/Agroforstsysteme $\% 20$ in $\% 20$ Deutschland-\% 20Landinfo.pdf

Deckers, B., Kerselaers, E., Gulinck, H., Muys, B. \& Hermy, M. (2005) Long-term spatio-temporal dynamics of a hedgerow network landscape in Flanders, Belgium. Environmental Conservation 32: 20-29.

Deimer, C., Heyer, W. \& Lüdigk, R. (2007) Evaluation des Entwicklungsplanes für den ländlichen Raum für den Interventionsbereich des EAGFL-Garantie im Förderzeitraum 2000 bis 2006 des Freistaates Sachsen, Bericht zur Ex-Post-Bemertung. Halle, Germany: SMUL.

Dupraz, P., van den Brink, A. \& Latacz-Lohmann, U. (2010) Direct income support and cross-compliance. In: EU Policy for Agriculture, Food and Rural Areas, ed. A. Oskam, G. Meester \& H. Silvin, pp. 351-362. Wageningen, the Netherlands: Wageningen Academic Publishers.

DVL (2010) Regionale Streuobstkreisläufe [www document]. URL http://sachsen.lpv.de/index.php?id=666

Eichhorn, M.P., Paris, P., Herzog, F., Incoll, L.D., Liagre, F., Mantzanas, K., Mayus, M., Moreno, G., Papanastasis, V.P., Pilbeam, D.J., Pisanelli, A. \& Dupraz, C. (2006) Silvoarable systems in Europe: past, present and future prospects. Agroforestry Systems 67: 29-50.

European Commission (1998) Anwendungsstand der Verordnung (EWG) Nr. 2078/92: Evaluation von Agrar- Umweltprogrammen. Arbeitsdokument VI 7655/98. Brussels, Belgium.

FAO (2000) Global Forest Resources Assessment 2000. Main Report. FAO Forestry Paper 140. Rome, Italy: UN Food and Agriculture Organization.

FAO (2001) Trees Outside the Forest: Tomards Rural and Urban Integrated Resources Management. Contribution to the Forest Resources Assessment 2000 Report. Rome, Italy: FAO Forest Conservation, Research and Education Service.

Fargione, J., Hill, J., Tilman, D., Polasky, S. \& Hawthorne, P. (2008) Land clearing and the biofuel carbon debt. Science 319: 1235-1238.

Fischer, J., Brosi, B., Daily, G.C., Ehrlich, P.R., Goldman, R., Goldstein, J., Lindenmayer, D. B., Manning, A.D., Mooney, A.H., Pejchar, L., Ranganathan, J., \& Tallis, H. (2008) Should agricultural policies encourage land sparing or wildlife-friendly farming? Frontiers in Ecology and the Environment 6: 380-385.

Gerowitt, B., Isselstein, J. \& Marggraf, R. (2003) Rewards for ecological goods: requirements and perspectives for agricultural land use. Agriculture, Ecosystems and Environment 98: 541-547.

Gibbons, P., Lindenmayer, D.B., Fischer, J., Manning, A.D., Weinberg, A., Seddon, J., Ryan, P. \& Barrett, G. (2008) The future of scattered trees in agricultural landscapes. Conservation Biology 22: 1309-1319. 
Goldman, R.L., Thompson, B.H. \& Daily, G.C. (2007) Institutional incentives for managing the landscape: inducing cooperation for the production of ecosystem services. Ecological Economics 64: 333-343.

Hagedorn, K. (2004) Property rights reform on agricultural land in Central and Eastern Europe. Quarterly Journal of International Agriculture 43: 409-438.

Hagedorn, K., Arzt, K. \& Peters, U. (2002) Institutional arrangements for environmental cooperatives: a conceptual framework. In: Environmental Cooperation and Institutional Change: Theories and Policies for European Agriculture, ed. K. Hagedorn, pp. 3-25. Cheltenham, UK: Edward Elgar.

Hampicke, U. (2001) Agrarumweltprogramme und Vorschläge für ihre Weiterentwicklung. In: Agrarummeltprogramme: Konzepte, Entwicklungen, künftige Ausgestaltung, ed. B. Osterburg \& H. Nieberg, pp. 97-109. Braunschweig, Germany: Landbauforschung Völkenrode.

Knickel, K., Janssen, B., Schramek, J. \& Käppel, K. (2001) Naturschutz und Landwirtschaft: Kriterienkatalog zur 'Guten fachlichen Praxis'. Schriftenreihe für Angewandte Landschaftsökologie 41. Bonn, Germany: BfN.

Kroeger, T. \& Casey, F. (2007) An assessment of market-based approaches to providing ecosystem services on agricultural lands. Ecological Economics 64: 321-332.

Manning, A.D., Gibbons, P. \& Lindenmayer, D.B. (2009) Scattered trees: a complementary strategy for facilitating adaptive responses to climate change in modified landscapes? fournal of Applied Ecology 46: 915-919.

Manning, A., Fischer, J. \& Lindenmayer, D. (2006) Scattered trees are keystone structures. Implications for conservation. Biological Conservation 132: 311-321.

McCollin, D. (2000) Hedgerow policy and protection: changing paradigms and the conservation ethic. Fournal of Environmental Management 60: 3-6.

Nair, P.K.R., Kumar, B.M. \& Nair, V.D. (2009) Agroforestry as a strategy for carbon sequestration. Fournal of Plant Nutrition and Soil Science 172: 10-23.

Nottmeyer-Linden, K., Müller, S., Horst, D. \& Wegge, J. (2000) Optimierung des Vertragsnaturschutzes im WarmenauProjekt: Zwischenergebnisse, Konzepte, Ziele. In: Zukunft des Vertragsnaturschutzes: Neue Konzepte zur Kooperation von Naturschutz und Landwirtschaft, ed. K. Nottmeyer-Linden, S. Müller, D. Horst \& B. Schweppe-Kraft, pp. 85-111. Bonn, Germany: BfN.

Osterburg, B. (2000) Impacts of agri-environmental programmes: the case of Germany. Background paper on a poster contribution at the 24th Conference of the International Association of Agricultural Economists (IAAE), 13-18 August 2000, Berlin, Germany [www document]. URL http://literatur.vti.bund.de/digbib_extern/zi023031.pdf

Pattanayak, S. \& Mercer, E. (1997) Valuing soil conservation benefits of agroforestry. American Fournal of Agricultural Economics 79: 1714-1714.

Philipp, H.-J. (1997) Abfolge und Bewertung von Agrarlandschaftswandlungen in Ostdeutschland seit 1945. Berichte über Landwirtschaft 75: 89-122.

Plieninger, T. (2011) Capitalizing on the carbon sequestration potential of agroforestry in Germany's agricultural landscapes: realigning the climate-change mitigation and landscape conservation agendas. Landscape Research 36: 435-454.
Plieninger, T. \& Schaar, M. (2008) Modification of land cover in a traditional agroforestry system in Spain. Processes of tree expansion and regression. Ecology and Society 13: 25.

Raudsepp-Hearne, C., Peterson, G.D. \& Bennett, E.M. (2010) Ecosystem service bundles for analyzing tradeoffs in diverse landscapes. Proceedings of the National Academy of Sciences USA 107: 5242-5247.

Reeg, T. (2008) Agroforstsysteme als interessante Landnutzungsalternative? Entscheidungsfaktoren für Landnutzer. Cottbuser Schriften zur Ökosystemgenese und Landschaftsentwicklung 6: 5368.

Ryszkowski, L. \& Kedziora, A. (2007) Modification of water flows and nitrogen fluxes by shelterbelts. Ecological Engineering 29: 388400.

Sayadi, S., González-Roaa, M.C. \& Calatrava-Requenaa, J. (2009) Public preferences for landscape features: the case of agricultural landscape in mountainous Mediterranean areas. Land Use Policy 26: 334-344.

Slangen, L.H.G. \& Polman, N.B.P. (2002) Environmental cooperatives: a new institutional arrangement of farmers. In: Environmental Cooperation and Institutional Change: Theories and Policies for European Agriculture, ed. K. Hagedorn, pp. 69-90. Cheltenham, UK: Edward Elgar.

SMLEF (1998) Sächsischer Agrarbericht 1997. Dresden, Germany: SMLEF.

SMUL (2009) Sächsischer Agrarbericht 2008. Dresden, Germany: SMUL.

SMUL (2010a) Daten zur Land- und Ernährungswirtschaft. Berichtsjahr 2009. Dresden, Germany: SMUL.

SMUL (2010b) Das Ökokonto in Sachsen. Ein neues Instrument zur Kompensation von Eingriffen in Natur und Landschaft. Dresden, Germany: SMUL.

Stern, K. (2003) Überlegungen zu einem zukunftsfähigen Agrarumweltprogramm. Berichte über Landwirtschaft 54: 5-27.

Swinton, S.M., Lupi, F., Robertson, G.P. \& Hamilton, S.K. (2007) Ecosystem services and agriculture: cultivating agricultural ecosystems for diverse benefits. Ecological Economics 64: 245252.

Tews, J., Brose, U., Grimm, V., Tielbörger, K., Wichmann, M.C., Schwager, M. \& Jeltsch, F. (2004) Animal species diversity driven by habitat heterogeneity/diversity: the importance of keystone structures. Fournal of Biogeography 31: 79-92.

Tisdell, C. \& Swarna Nantha, H. (2007) Comparison of funding and demand for the conservation of the charismatic koala with those for the critically endangered wombat Lasiorhinus kreffiii. Biodiversity and Conservation 16: 1261-1281.

van der Horst, D. (2006) A prototype method to map the potential visual-amenity benefits of new farm woodlands. Environment and Planning B-Planning and Design 33: 221-238.

Vatn, A. (2010) An institutional analysis of payments for environmental services. Ecological Economics 69: 1245-1252.

Verchot, L.V., Van Noordwijk, M., Kandji, S., Tomich, T., Ong, C., Albrecht, A., Mackensen, J., Bantilan, C., Anupama, K.V. \& Palm, C. (2007) Climate change: linking adaptation and mitigation through agroforestry. Mitigation and Adaptation Strategies for Global Change 12: 901-918.

Wätzold, F. \& Schwerdtner, K. (2005) Why be wasteful when preserving a valuable resource? A review article on the costeffectiveness of European biodiversity conservation policy. Biological Conservation 123: 327-338. 
Weins, C. (2001) Schritt zur Agrarwende: Die 'gute fachliche Praxis' konkretisieren. Zeitschrift für Ummeltrecht 11: 247-249.

Winkler, B., Hofmann, E., Ullrich, F. \& Heinrich, K. (2010) Eigentumsentwicklung an Boden. Analyse, Ursachen, Wirkungen der Eigentumsentwicklung an Boden nach Rechtsformen. Schriftenreihe des Landesamtes für Umwelt, Landwirtschaft und Geologie 1/2010. Dresden, Germany: LfULG.
Zander, K. \& Waibel, H. (2005) Die Zahlungsbereitschaft für traditionelle Formen der Landbewirtschaftung: das Beispiel 'Streuobst'. Zeitschrift für Umweltpolitik und Umweltrecht 28: 109126.

Zhang, W., Ricketts, T.H., Kremen, C., Carney, K. \& Swinton, S.M. (2007) Ecosystem services and dis-services to agriculture. Ecological Economics 64: 253-260. 